\title{
Epilogues and last words in Shakespeare: exploring patterns in a small corpus
}

\author{
Alison Findlay \\ Lancaster University, UK
}

\begin{abstract}
This article considers the linguistic features of the speeches that end Shakespeare's plays, some of which are formally labelled as Epilogues. It introduces a play's last words as a type of paratext using the theoretical models devised by Genette (1997), and then considers the material evidence surrounding Epilogues, a specific form of last words, using research on their ephemeral and occasional nature by Stern (2009). The difficulties of using corpus methods in the case of small, specialist subcorpora of paratexts is then considered and the methodology adopted to extract and present the results is outlined. The demonstrates features of the Last Words corpus: how pronouns raise questions about the speaker's stance (with reference to work by Goffman, 1979, and Messerli, 2017); how these speeches deploy the language of inclusivity; how they interpellate spectators or readers to promote a specific agenda. Because last words enact the fragile liminal moment where characters, actors and audience are united by their experience of the performance, the article considers their retrospective and prospective orientation. It demonstrates how the prominence of verbs like 'shall' and 'will' can be used for marketing purposes. The problems raised by uneven dispersion of terms is discussed leading to a case study of the Epilogue of As You Like It which demonstrates how its use of language is deliberately linked to the discursive world of the play which precedes it.
\end{abstract}

\section{Keywords}

Shakespeare, Epilogues, last words, As You Like It, paratext, spectators, address, dispersions; interpellation

\section{Introduction}

'Give me thy last words' (5.6.89) ${ }^{1}$ says Palamon to Arcite in the last scene of the last play Shakespeare wrote as he handed the job of King's Men's playwright to his co-author, John Fletcher. This article considers the linguistic features of the 'last words' - the final speeches of texts in the plays of Shakespeare, including those formally labelled as 'Epilogues'. It introduces last words as a particular type of paratext, using the theoretical models devised by Genette (1997), and then considers the occasional and ephemeral nature of epilogues, as researched by Stern (2009). The difficulties of using corpus methods in the case of a specialist subgroup of paratexts is then considered and the methodology adopted to analyse such a small corpus is outlined. A consequence of low-frequency is that the full armoury of 
corpus-based techniques underpinned by inferential statistics (e.g. collocation, keywords), as demonstrated in other papers in this special issue, cannot be deployed as the centrepiece here; instead, this paper takes a somewhat more literary tack, showing how, nevertheless, corpusbased methods still have a role to play. The comparative frequency of words within the subcorpora of last words and epilogues as opposed to the subcorpus of the rest of the plays provides the data for the analyses which follow. The article discusses pronouns and forms of address in last words, through which spectators or readers are incorporated into the theatrical community of the performance and can be influenced. It discusses the dispersion of words in the epilogues of Shakespeare's plays and in the full texts of those plays. A case study of the language of As You Like It demonstrates the symbiotic relationship between the play's last words and the text that precedes them.

\section{Epilogue and paratext}

Genette's study of paratexts in books (1997) helps to define a play's last words, which stand at the 'threshold' between the play and the world beyond it. Genette defined a paratext as a 'vestibule,' between the text and the outside, 'a zone not only of transition but also of transaction: a privileged place of pragmatics and strategy' to promote 'a better reception for the text and a more pertinent reading of it' in 'the eyes of the author and his allies' (1997: 2) He subdivided the category of paratexts into 'peritexts' which exist inside the book (like prefaces, title pages, dedications), and 'epitexts' which perform this function outside the book (like publicity materials, reviews, interviews with the author) (1997: 5). If we apply Genette's model to dramatic texts, prologues and epilogues are peritexts that happen within the walls of the theatre or the covers of the published book of the script. Genette's description of paratexts as 'an airlock that helps the reader pass without too much respiratory difficulty from one world to the other, a sometimes delicate operation, especially when the second world is a fictional one' (1997: 408) fits the theatrical context very effectively. Spectators and readers are welcomed into the fictional world via the 'vestibule' of the prologue; the last words of the play function as an airlock to conduct them from the playworld back into their own social milieu (and through the doors of the theatre after a performance). Solomon (2013) has shown how, following the Restoration, prologues and epilogues became much more visible than in Shakespeare's day, and performed their mediatory function in both performances and in printed forms (Solomon, 2013: 13). Indeed, the importance of epilogues is demonstrated by 
the fact that Restoration spectators 'took elaborate measures to attend performances of prologues and epilogues' (Solomon, 2013: 9). A parallel practice in Shakespeare's theatre was instances of spectators arriving at the end of a performance specifically to see the clown, Will Kempe perform a 'jig' at the end of the play. Other Restoration spectators 'made a point of leaving before the epilogue' supposedly to maintain the illusion of a play, particularly a tragedy (Solomon 2013: 10). The epilogue to The Two Noble Kinsmen, whose action ends surprisingly with the death of the supposed victor, Arcite, fears that the audience will leave, asking them 'Pray, yet stay awhile ... No man smile?' and 'Tis in vain, I see, to stay ye' (Epilogue 3-4, 10). Even though we do not have as much evidence for the practices of playgoers in Shakespeare's day, we do well to remember Gray's (2010) observation (from the modern media), that 'paratexts are not simply add-ons, spinoffs, and also-rans: they create texts, they manage them, and they fill them with many of the meanings that we associate with them' (Gray, 2010: 6). For this reason, a study of the last words in Shakespeare's plays is important.

Having said this, the 'terminal paratext' is a surprisingly under-recognized phenomena as Sherman (2011) has pointed out. The majority of early modern printed books conclude with the simple Latin word finis, a word that is nevertheless 'one of the most interesting speech acts in the history of the language' because it 'announces and effects the ends of words' (Sherman, 2011: 73). Finis marks the end of all but one of the plays in the First Folio (the exception is King John). ${ }^{2}$ In performance, however, the last words spoken are the terminal paratext, releasing spectators and performers from the playworld. In most cases, these are not marked off by the word 'Epilogue'. Indeed, Schneider (2013) points out the term is an innovation of the early modern period since "no such custom exists in classical drama to encourage the form in which it developed in early modern plays' (Schneider, 2013: 51). Even though the earliest entry for epilogue in the OED (Oxford English Dictionary) is 1564, the practice of a paratextual speech, addressed to spectators and containing self-conscious theatricality was a prominent feature of medieval drama and interludes (Schneider, 2013: 55). Epilogues are a distinctive but ephemeral genre; Stern (2009) has shown that, like prologues, they were 'regularly changed, lost, found, and printed elsewhere, as befits manuscripts written outside the playbook and not necessarily intended to survive with it' (Stern, 2009: 82). They are occasional texts, designed specifically for the moment of performance, often a particular performance, audience and venue. Stern's view is that surviving examples are 'generally for first performances' (2009: 82) and that they enact what is effectively, a trial 'of 
the playscript itself' (2009: 89). As a discursive genre, then, epilogues offer a coda to the performance of a playscript like the summing up of an advocate, or perhaps more neutrally a judge, at the end of a trial. This analogy highlights another important feature of the epilogue: its voice is not that of the playwright. Indeed, as Stern points out, many epilogues were not written by the authors of the playscripts. This is immaterial with reference to the current project for, as Foucault (1977) pointed out, a modern idea of the author is not applicable to early modern culture, and we know that playscripts were owned by the theatre companies rather than by a single author. Our approach in the Encyclopedia of Shakespeare's Language project has been to survey all text which appears in the First Folio of $\mathrm{Mr}$ William Shakespeares Comedies, Histories, \& Tragedies, published in 1623, with the addition of Pericles and The Two Noble Kinsmen, two plays in which Shakespeare collaborated, the first with George Wilkins and the latter with John Fletcher. These two plays have been traditionally canonised and embraced by the term 'Shakespeare' even though they were not included in the First Folio. The 1623 Folio does print texts which are collaborations between Shakespeare and other playwrights (such as Henry VIII, Henry VI Parts I and II, Measure for Measure and Macbeth). The First Folio also shows evidence of collaboration between the writer William Shakespeare and other members of the theatre company, notably his two fellow actors John Heminges and Henry Condell who edited the Folio.

Their Preface to 'the great Variety of Readers,' casts useful light on the nature of epilogues in relation to judgement of a play. Heminges and Condell address readers as a Prologue might address spectators in a theatre. By buying the book, itself a form of advocacy, purchasers will insist on their 'privileges' to 'read and censure'. They will judge like 'Magistrates of wit' who 'sit on a Stage at Black-friars, or the Cock-pit, to arraigne Playes dailie.' However, Heminges and Condell move on to write more in the tone of an Epilogue, reminding readers that 'these Playes have had their triall already,' and are now published '[ac]quitted' by 'a Decree of Court.' Given what Stern (2009) argues about the occasional, detached nature of epilogues, it is significant that Heminges and Condell include 8 epilogues in their collection of playscripts by Shakespeare which they say are as perfect 'in all their limbs' and 'absolute in their numbers, as he conceived them'. This suggests that the epilogues are integral to the playscript as a whole and are probably 'conceived' as such by Shakespeare the playwright, whatever hands went into composing and performing them. The case study in Section 4 pursues this argument. There are probably many more epilogues to Shakespeare's plays than those which have come down to us in printed form. Pericles and The Two Noble Kinsmen, for 
instance, the two non-Folio collaborative plays included in the Encyclopedia of Shakespeare's Language corpus, both have epilogues. So does Arden of Faversham, admitted to the canon in the New Oxford Shakespeare (Taylor et al., 2016). The epilogues printed in the First Folio thus serve to remind readers of the theatrical origins of the material and to reposition them as 'Magistrates of wit' with the right to judge the First Folio itself, as they may have previously censured and 'quitted' the plays in the theatres.

The relative scarcity of epilogues in the First Folio is not surprising given their transient and occasional nature and the under-use of the term in early modern English. In the sample segment of EEBO-TCP used as comparative context to Shakespeare's plays in the Encyclopedia of Shakespeare's Language project, for example, there are a mere 331 instances in a corpus of some 300 million words. Alternative ways of ending a play are also present in the Enhanced Shakespearean Corpus: First Folio Plus. At the end of the performance of 'Pyramus and Thisbe' in A Midsummer Night's Dream, Theseus insists 'no, epilogue I pray you: for your play needs no excuse' and chooses a 'Bergomask dance' by Peter Quince's company of actors instead (5.1.342-3). Much Ado About Nothing likewise concludes with a dance, deliberately repeating the masked ball of 2.1. In Love's Labour's Lost, a concluding song is followed by a dismissal 'You that way, we this way' (5.2.914) which serves to part the actors playing the characters and the spectators. In public performances, the last words of a play were often followed by a Jig; sometimes a solo comic song and dance routine by the Clown, as the Epilogue to Henry IV Part II alludes to (Epilogue 30-2) or a short sketch combining comic bawdy song, dance, mock combat. ${ }^{3}$ Stern (2010) noted that prayers to the monarch were an additional paratext, perhaps following first performances in which Epilogues prayed for the success of the play as well as for the monarch. The Epilogue of Henry IV Part II, for example, ends by saying he will 'kneel down before you - but, indeed, to pray for the Queen' (line 33). Epilogues by Prospero and Richmond in Richard III deliberately incorporate the prayers that spectators and actors were invited to offer to the monarch (see below).

Genette (1997) dismisses the power of last words, or what he calls 'postfaces,' to hold the readers' attention and guide their reading of the text, as prefaces do. While postscripts in books may fail because they are 'always both too early and too late' to make corrections, this is, arguably, not so in a live performance. Their power to engage spectators and readers by direct address and thus their 'curative, or corrective, function' (Genette, 1997: 239) should not be underestimated. Their words may unfix what has been assumed at the play's closure 
(as, for example, in As You Like It, where the Epilogue undoes the heteronormative marriages), as well as re-articulating a message that has emerged from the action of the play. Hamlet's epilogue to 'The Mousetrap', the play-within-the-play in Hamlet, for example, draws out the moral of the on-stage performance for the most important spectator, Horatio:

Why, let the stricken deer go weep,

The hart ungallèd play,

For some must watch, while some must sleep,

Thus runs the world away. (3.2.259-62)

There are multiple layers of meaning in this epilogue, supplied by Hamlet when Claudius gets to his feet and exits in distress. The most immediate meaning is that the guilty Claudius is the stricken deer, since the emblem of a deer with an arrow in its side represented a guilty man in Peacham's Minerva Brittana (Peacham,1612: 4). The hart is Hamlet himself, who is carefully watching to 'catch the conscience of the king' (2.2.607), while Claudius 'sleep[s]'. Hamlet prepares for the epilogue in a paratextual comment which uses a metaphor of horses, and is delivered mid-action, just before the staged murder: 'Let the galled jade wince; our withers are unwrung' (3.2.231). At another level, Hamlet's epilogue replays the past history of his father's murder stricken with poison while sleeping in the orchard, from which Claudius appears to have run away with the 'world' of the Danish crown 'ungallèd' - that is, without a prick of conscience. In the wider context of Hamlet, this mid-play paratext functions like Gray's example of a 'carefully edited fifteen to thirty second sequence of images and plot points from previous episodes' in a television series, to give audiences 'necessary backstory' and so inflect their 're-entry to television texts' (Gray, 2010: 42). 'The Mousetrap' replays the past as Hamlet and the ghost believe it to have happened, but it also plays out a threatening future for Claudius in the staged murder of a ruler by his nephew (Hamlet). Having watched this, spectators and readers hear or read the moral in Hamlet's epilogue and are prepared to re-enter the plot of Hamlet in Act 3 Scene 3, with a new perspective. Is Claudius guilty as charged, as seems to be the case, or is Hamlet the regicide, deluded by the ghost's story which he wants to believe? In Act 3 Scene 3, Claudius confesses his guilt (the first time that the audience know for sure he has committed regicide and fratricide). He also plots against Hamlet, realizing he is 'too free-footed' (3.3.26) to remain at large in Denmark. Hamlet then enters, with an ideal opportunity to murder Claudius while he is alone and is unaware, because he is trying to pray. The Epilogue to 'The Mousetrap' 
prepares spectators for all these possibilities. It shows how last words can shape and reshape the understanding of on and off-stage spectators.

\section{Corpus preparation, extraction and results}

Given that the last words of a play (whether as a formal epilogue or the final speech or dialogue) are significant in shaping and reshaping understanding of the play that has preceded them, a study of their language as a group of paratexts and in relation to the texts which they terminate offers a useful avenue for research. Solomon (2013), for example, argues 'it is time for prologues and epilogues to be treated systematically' (2013: 9). The software used for searching the last words of Shakespeare's texts is CQPweb (Corpus Query Processor), a webbased corpus analysis system designed by Andrew Hardie, which has been used throughout the Encyclopedia of Shakespeare's Language project. ${ }^{4}$ As a method of corpus analysis, keyword searching certainly has the potential to illuminate linguistic features of the epilogue or last words as a sub-genre of dramatic discourse. Firstly, in creating a subcorpus called 'Epilogues,' we were aided by a tagging system implemented for our Enhanced Shakespearean Corpus: First Folio Plus. Using CQPweb. All plays in the Enhanced Shakespearean Corpus are marked up and annotated with XML tags (see Bray et al. 2008; Hardie 2014). Each utterance is marked with an opening speaker ID tag and a close tag. Act and scene boundaries, stage directions, front matter, end matter and, crucially for our purposes here, paratext are marked with XML tags. We simply downloaded the speeches we had tagged as epilogues and added manually the three spoken epilogues to entertainmentswithin-plays in Hamlet (above), Prospero's 'Our revels now are ended' at the end of the masque in The Tempest (4.1.148-63), and the schoolmaster's speech at the end of the Mayday Morris presented to Theseus and his court in Two Noble Kinsmen (3.5.139-48). However, this 'Epilogues' subcorpus from the ends of 10 plays (All's Well That Ends Well, A Midsummer Night's Dream, As You Like It, Henry IV Part II, Henry V, Henry VIII, Pericles, The Tempest, Troilus and Cressida, The Two Noble Kinsmen) and the 3 epilogues to entertainments-within-plays, is too small to run inferential statistical tests or to generalise on the basis of them. The last speeches in other plays share, variously, the paratextual quality of the formally labelled epilogues, so we created a second subcorpus called 'Last Words' made up of all the texts in the first 'Epilogues' subcorpus plus the last words of the plays that are not formally labelled as epilogues by printers, actors or author. The only play whose final 
words we did not include was Much Ado About Nothing because this ends with a dance which has its own significant, non-verbal link to the play which has preceded it.

To compare the use of language in the 'Last Words' subcorpus with that in the rest of the plays, a third subcorpus 'Rest of Plays' was created manually from the texts in the Enhanced Shakespearean Corpus: First Folio Plus. The subcorpus of 'Last Words' in Shakespeare (2078 words) is still very small to analyse in comparison to the 'Rest of Plays' subcorpus. For the purposes of this study it was therefore necessary to depart from the methods of analysis used elsewhere in the Encyclopedia of Shakespeare's Language project, such as collocations and keywords. Instead, frequency counts for the subcorpora were achieved with AntConc version 3.4.4 for Windows. ${ }^{5}$

Table 1 shows the results of a simple rank-ordered frequencies profile of the words which occur in the three subcorpora of the Enhanced Shakespearean Corpus: First Folio Plus. The column on the left, 'Last Words', lists frequencies of words in the subcorpus containing the last speeches including song lyrics in these plays, and including those formally labelled as 'Epilogues' and words that occur at the end of plays-within-plays. ${ }^{6}$ Column 2, 'Rest of Plays', gives the frequency of all the words in all the rest of these texts (37 plays including Pericles and Two Noble Kinsmen but not including Much Ado About Nothing) for comparison. On the right hand side are listed frequencies of words occurring in those last words identified as 'Epilogues', including those which occur at the end of performances within plays. ${ }^{7}$ In addition, the far right column displays a statistic indicating the degree of dispersion of a particular word across the Epilogues subcorpus. The dispersion measure, supplied by \#LancsBox (v.5), is coefficient of variation, which shows standard deviation relative to the mean; the higher the number the less well dispersed the word. ${ }^{8}$ In the analysis which follows, the labels Last Words, Rest of Play and Epilogues will be used without quotation marks to refer to these subcorpora.

Table 1. Rank-ordered word frequencies in the last words of plays, the rest of plays (i.e. minus last words and epilogues), and all epilogues 


\begin{tabular}{|c|c|c|c|c|c|c|c|}
\hline \multirow[t]{2}{*}{ Rank } & \multicolumn{2}{|c|}{ Last words } & \multicolumn{2}{|c|}{ Rest of plays } & \multicolumn{3}{|c|}{ Epilogues } \\
\hline & Word & $\begin{array}{l}\text { Absolute } \\
\text { frequency } \\
\text { (Relative } \\
\text { frequency per } \\
\text { million words) }\end{array}$ & Word & $\begin{array}{l}\text { Absolute } \\
\text { frequency } \\
\text { (relative } \\
\text { frequency per } \\
\text { mission words) }\end{array}$ & Word & $\begin{array}{l}\text { Absolute } \\
\text { frequency } \\
\text { (relative } \\
\text { frequency per } \\
\text { million words) }\end{array}$ & $\begin{array}{l}\text { Dispersion } \\
(\mathrm{CV})\end{array}$ \\
\hline 1 & the & $173(401.578)$ & the & $27415(331.558)$ & and & $60(384.615)$ & 0.256 \\
\hline 2 & and & $171(396.936)$ & and & $24887(300.984)$ & the & $51(326.923)$ & 0.375 \\
\hline 3 & to & $99(229.805)$ & I & $19901(240.683)$ & you & $39(250)$ & 0.807 \\
\hline 4 & $\mathrm{a}$ & $73(169.452)$ & to & $18590(224.828)$ & $\mathrm{I}$ & $38(243.590)$ & 0.980 \\
\hline 5 & of & $72(167.131)$ & of & $16441(198.838)$ & to & $38(243.590)$ & 0.661 \\
\hline 6 & I & $70(162.488)$ & $\mathrm{a}$ & $14102(170.550)$ & is & $27(173.077)$ & 0.720 \\
\hline 7 & you & $69(160.167)$ & you & $13577(164.201)$ & of & $25(160.256)$ & 0.871 \\
\hline 8 & in & $56(129.991)$ & my & $12091(146.229)$ & my & $24(153.846)$ & 1.513 \\
\hline 9 & that & $56(129.991)$ & in & $10917(132.030)$ & for & $23(147.436)$ & 0.833 \\
\hline 10 & this & $53(123.027)$ & that & $10671(129.055)$ & $\mathrm{a}$ & $21(134.615)$ & 0.687 \\
\hline 11 & for & $49(113.742)$ & is & $10542(127.495)$ & that & $21(134.615)$ & 0.498 \\
\hline 12 & is & $49(113.742)$ & not & 9077 (109.777) & in & $20(128.205)$ & 0.979 \\
\hline 13 & with & 47 (109.099) & it & $8727(105.545)$ & your & $20(128.205)$ & 0.744 \\
\hline 14 & we & $46(106.778)$ & me & $7906(95.615)$ & not & $19(121.795)$ & 0.673 \\
\hline 15 & my & $44(102.136)$ & for & $7537(91.153)$ & if & $18(115.385)$ & 0.998 \\
\hline 16 & as & $36(83.565)$ & with & $7495(90.645)$ & me & $17(108.974)$ & 0.902 \\
\hline 17 & be & $36(83.565)$ & be & $6805(82.300)$ & be & $16(102.564)$ & 1.031 \\
\hline 18 & our & $35(81.244)$ & his & $6787(82.082)$ & good & $16(102.564)$ & 1.643 \\
\hline 19 & but & $34(78.923)$ & your & $6695(80.969)$ & have & $16(102.564)$ & 1.026 \\
\hline 20 & it & $34(78.923)$ & this & $6580(79.579)$ & it & $16(102.564)$ & 0.895 \\
\hline 21 & your & $34(78.923)$ & he & $6252(75.612)$ & will & $16(102.564)$ & 0.937 \\
\hline 22 & all & $32(74.280)$ & but & $6067(73.374)$ & this & $15(96.154)$ & 0.785 \\
\hline 23 & not & $32(74.280)$ & have & $5931(71.730)$ & we & $15(96.154)$ & 1.378 \\
\hline 24 & will & $32(74.280)$ & as & $5623(68.005)$ & with & $15(96.154)$ & 0.690 \\
\hline 25 & shall & $30(69.638)$ & thou & $5395(65.247)$ & as & $14(89.744)$ & 1.228 \\
\hline 26 & have & $29(67.317)$ & him & $5156(62.357)$ & but & $14(89.744)$ & 0.896 \\
\hline 27 & by & $27(62.674)$ & will & $4948(59.841)$ & his & $13(83.333)$ & 1.527 \\
\hline 28 & his & $27(62.674)$ & so & $4908(59.357)$ & here & $11(70.513)$ & 0.713 \\
\hline
\end{tabular}




\begin{tabular}{|c|c|c|c|c|c|c|c|}
\hline \multirow[t]{2}{*}{ Rank } & \multicolumn{2}{|c|}{ Last words } & \multicolumn{2}{|c|}{ Rest of plays } & \multicolumn{3}{|c|}{ Epilogues } \\
\hline & Word & $\begin{array}{l}\text { Absolute } \\
\text { frequency } \\
\text { (Relative } \\
\text { frequency per } \\
\text { million words) }\end{array}$ & Word & $\begin{array}{l}\text { Absolute } \\
\text { frequency } \\
\text { (relative } \\
\text { frequency per } \\
\text { mission words) }\end{array}$ & Word & $\begin{array}{l}\text { Absolute } \\
\text { frequency } \\
\text { (relative } \\
\text { frequency per } \\
\text { million words) }\end{array}$ & $\begin{array}{l}\text { Dispersion } \\
(\mathrm{CV})\end{array}$ \\
\hline 29 & so & $27(62.674)$ & what & $4487(54.266)$ & our & $11(70.513)$ & 1.172 \\
\hline 30 & good & $23(53.389)$ & her & $3807(46.042)$ & so & $11(70.513)$ & 0.710 \\
\hline 31 & if & $23(53.389)$ & thy & $3805(46.018)$ & all & $10(64.103)$ & 1.056 \\
\hline 32 & let & $23(53.389)$ & do & $3795(45.897)$ & play & $10(64.103)$ & 1.075 \\
\hline 33 & $\mathrm{me}$ & $23(53.389)$ & no & $3707(44.833)$ & $\mathrm{t}$ & $10(64.103)$ & 1.733 \\
\hline 34 & are & $22(51.068)$ & all & $3671(44.397)$ & now & $9(57.692)$ & 1.106 \\
\hline 35 & us & $21(48.747)$ & shall & $3618(43.756)$ & which & $9(57.692)$ & 1.190 \\
\hline 36 & here & $19(44.104)$ & by & $3591(43.430)$ & by & $8(51.282)$ & 1.422 \\
\hline 37 & now & $19(44.104)$ & if & $3519(42.559)$ & then & $8(51.282)$ & 1.327 \\
\hline 38 & then & $18(41.783)$ & are & $3402(41.144)$ & ye & $8(51.282)$ & 3 \\
\hline 39 & when & $18(41.783)$ & we & $3392(41.023)$ & $\mathrm{am}$ & $7(44.872)$ & 1.578 \\
\hline 40 & what & $17(39.461)$ & our & $3178(38.435)$ & no & $7(44.872)$ & 1.577 \\
\hline
\end{tabular}

\section{Analysis}

The following analysis begins by comparing the use of pronouns and forms of address used in the Last Words as opposed to the Rest of Play. The question of whose voice is speaking, the importance of inclusivity in terms of address, and the discursive powers of interpellation in terminal paratexts are discussed in section 4.1. How the prominence of verbs like 'shall' and 'will' give the last words of the play a prospective as well as a retrospective function and how they function as marketing tools is considered in section 4.2. The problems raised by uneven dispersion of some of the words in the table is outlined in section 4.3, leading finally to a case study of As You Like It (section 4.4) to demonstrate that last words can be deliberately linked to the language of the play which precedes them.

\subsection{Terms of address}

As performative texts, epilogues speak on behalf of the company, rather than on behalf of a single author. They are spoken by a single actor who brings his ${ }^{9}$ own interests in (and 
perspective on) the script, often both as actor and as character, and yet he also speaks for his fellow players and for the shareholders of the company. 'Who is speaking?' is thus a complex question at the threshold moment of the play's paratext. The uncertainty of whether an actor or character is speaking inside or outside the fiction at such points has a long stage history, going back at least to late medieval drama as Belsey (1985: 181) pointed out. Messerli (2017) has used Goffman's work on 'footing' (1979) to differentiate three elements of scripted speech: that of the animator (who vocalises the utterance), the author (who formulates it) and the principal (whose set of beliefs are being expressed in language) (Goffman, 1979: 16-17). Messerli argues that, in fictional discourse, 'these roles are separated' (2017: 32). However, when the animator utters the final words of a play, the overlap between these roles is advertised by his use of singular and plural pronouns. It is no surprise to find that that, alongside 'I' (4 in Epilogues or 6 in Last Words); and 'you' (3 in Epilogues and 7 in Last Words), the use of plural pronouns ranks significantly highly in Last Words. 'Our' appears at (18) in Last Words in comparison to (40) in Rest of Play; 'we' appears at point 14 in Last Words and at (39) in Rest of Play. In contrast, the singular possessive pronoun 'my' is ranked 8 in Rest of Play but only 15 in Last Words. The preference for plural form pronouns in Last Words or Epilogues indicates that these are spoken simultaneously by the company of animators, the author(s) and the principal (or the shareholders of the theatre company) through the voice of animator.

Addressees are also strategically constructed by the language of epilogues and last words. Messerli (2017) outlines how pragmatic research on cinema and television has focussed on the various levels or layers of audience participation in scripted and performed speech, showing how Goffman recognised that this model needed modification in the case of theatregoing. Nevertheless, he maintains Goffman's idea that 'the audience is given the information it needs covertly, so the fiction can be sustained' (Goffman, 1986: 142), explaining that the playwright makes 'particular information available to audiences, while still maintaining the illusion' (Messerli, 2017: 147). Whether any kind of 'illusion', or 'suspension of disbelief ${ }^{10}$ operated in the early modern theatre is highly questionable, and when the speaker of an epilogue or play's last words explicitly crosses the boundary from the fictional world into that of the spectators by addressing them directly, he deliberately blends the worlds and levels of participation. The use of 'you' as opposed to 'thee / thou' (which is usually more intimate or condescending) is appropriate to one respectfully addressing those 
on whom he and his company depend for their livelihoods. It is higher ranked in the Epilogues (3) than Last Words (7) and Rest of Play (7) corpora. The speaker who performs the Epilogue to Henry IV Part II refers deferentially to 'you, my gentle creditors' (12), i.e. those who have invested in him and the play by paying their entrance fees, and those who believe in him and what he says. In curtseying to spectators 'in duty' he appeals on behalf of 'our humble author' and the company, 'to beg your pardons' for any shortcomings, and for future patronage. Puck too appeals to spectators as 'Gentles' to be gentle in their responses, promising 'If you pardon, we will mend' (Epilogue 7-8). In All's Well the Epilogue (spoken by the actor who played the King of France) announces himself with the words 'The King's a beggar now the play is done' and uses inclusive plural pronouns to create a symbiotic relationship between company and spectators: 'Ours be your patience then, and yours our parts: / Your gentle hands lend us, and take our hearts' (Epilogue 1, 5-6). Even the speaker who has been playing the role of the powerful Prospero in The Tempest ends the play without his magic and dependent on spectators: 'Let your indulgence set me free' (Epilogue 20).

'You', as the plural form of the relatively formal second-person pronoun, also indicates that last words are spoken to spectators as a community, rather than to individuals. Whereas the Rest of Play features frequent uses of the intimate 'thou' (25), 'thy' (31), and 'thee' (43) these pronouns appear nowhere in the top 50 rankings for Last Words (or Epilogues). The only last words in which 'thou / thy' is used as a form of address for spectators is in Timon's epitaph, cursing those on and off stage from his grave collectively as 'you wicked caitiffs' (5.5.74) because they hated him in life: 'Pass by, and curse thy fill, but pass and stay not here thy gait' (5.5.77-8). Read aloud by Alcibiades at the end of Timon of Athens, this is a very unusual way to send individual spectators off through the doors of the theatre, followed, as these words are, with the grim prophecy that peace and war will feed off each other like parasites in the future (5.5.88-9). They are, of course, brilliantly appropriate last words for a tragedy about misanthropy.

Last Words and Epilogues show slightly more frequent use of the inclusive term 'all' (rank position 22 in Last Words; 31 in Epilogues) than in Rest of Play (34) as another means to forge a community with and amongst spectators / readers. In the illustrative examples below they are highlighted in bold. At the ending of Merry Wives of Windsor, for example, Mistress Page invites 'Sir John and all' to 'laugh this sport over by a Country fire' (5.5.234-5). In the final speech of Cymbeline the King, as mouthpiece for both the King's Men company and the 
agenda of James I, pronounces 'Publish we this Peace / To all our Subjects' (5.6.479-80). Such inclusive language can give the paratext power to interpellate readers or viewers to share an ideology promoted by the play (Goffman's principal). The fact that 'prayer and epilogue were so long linked together', as Stern notes (2010: 126), enhances this effect. Richard III, for example, uses the convention of ending a performance with prayers to the monarch (referred to by the Epilogue in 2 Henry $I V$ ), in order to interpellate spectators into applauding its Tudor agenda, or reading of history. The animator of these words speaks as the character Richmond, newly crowned as Henry VII, and also as principal, giving voice to a Tudor ideology or set of beliefs self-consciously promoted by Queen Elizabeth's playing company, the Lord Chamberlain's Men, and apparently by their author. The final speech celebrates Richmond's victory with a marriage that will unite 'the white rose and the red' (5.6.22). The speaker warns spectators and readers 'What traitor hears me and says not “Amen"?' (5.5.22) before ending the play with a prayer for peace:

Let them not live to taste this land's increase,

That would with treason wound this fair land's peace.

Now civil wounds are stopped; peace lives again.

That she may long live here, God say 'Amen'.

$$
\text { (5.5.38-41). }
$$

Spectators are interpellated as loving subjects of Queen Elizabeth, whose presence and peaceful government is invoked in the pronoun 'she'. Who in the audience would dare to be regarded as a traitor by refusing to say "amen" (we agree)? The 'Amen' that concludes the play assumes applause from all for the peace, thus declaring their allegiance to the monarch, the status quo, and the common good, rather than to the stark individualism that characterised Richard III's career. ${ }^{11}$ The animator, speaking with the authority of his character as the first Tudor monarch, thus commands obedience from the subjects (addressees) of the last Tudor monarch, inviting them all to collaborate in the myth of Tudor unity in which they are presently living. In The Tempest, the prayer-epilogue spoken by the actor who played the once-powerful magician Prospero is undoubtedly a more humble petition (Epilogue 1-20). However, by appealing for the 'help of your good hands' to pardon his 'crimes' and send him home to Naples (6), he is, arguably, asking them to endorse incipient colonial power. This is uncomfortable for many readers or spectators in the twenty-first century and it is arrogant to assume it was not so for some of Shakespeare's contemporaries too. As the Epilogue of 
Henry VIII, astutely points out ' Tis ten to one this play will never please / All that are here' $(1-2)$.

\subsection{Last words and time}

The final speech of King John cautions 'Oh let us pay the time but needful woe' and goes on to confidently predict 'This England never did, nor never shall / Lie at the proud foot of a Conqueror' (5.7.110-12). The use of a future marker (marked in bold in this section) in the last words of a play suggests that terminal paratexts do not, as we might expect, simply look back over the text or performance which precedes them. In fact, all but 4 of the 40 examples of Last Words make reference to the future, a feature captured in the prominence of the words 'shall' (ranked 25 in Last Words and 35 Rest of Play) and 'will' (24 Last Words, 21 Epilogues and 27 Rest of Play). ${ }^{12}$ This raises important questions: are last words retrospective or prospective or both and, if so, why? In some comedies (Twelfth Night, Midsummer Night's Dream, All's Well, and the epilogue to the Morris in The Two Noble Kinsmen), the speaker uses will or shall to promise future (superior) performances. Figure 1 below illustrates these prospective future markers will and shall in the Epilogues subcorpus.

\section{Figure 1. Showing occurrences of future markers in the CQPweb Epilogues subcorpus}

\begin{tabular}{|c|c|c|c|c|}
\hline \multicolumn{2}{|c|}{ Your query "will", restricted to Scene regions with "Scene type: epilogue", returned 15 matches in $\mathbf{6}$ different texts (in 1,537 words [8 Scene } \\
units]; frequency: 9,759.271 instances per million words) $[0.387$ seconds]
\end{tabular}

\begin{tabular}{|c|c|c|c|}
\multicolumn{5}{|c|}{ Your query "shall", restricted to Scene regions with "Scene type: epilogue", returned $\mathbf{3}$ matches in $\mathbf{3}$ different texts (in 1,537 words [8 Scene units]; } \\
frequency: 1,951.854 instances per million words)
\end{tabular}


The epilogue to The Two Noble Kinsmen, for example, assures spectators 'ye shall have ere long / Many a better to prolong / Your old loves to us' (15-17). The epilogue is a tool to persuade audiences to return. In the last words of tragedies, a sense of catharsis can sometimes by glimpsed, as in Edgar's 'The weight of this sad time we must obey,' followed by the recognition 'we that are young, / Shall never see so much, nor live so long' (King Lear 5.5.3.299-302). The last words of the history plays invariably take advantage of the paradox that in looking toward the future they are retelling the past. Thus, when Henry VII asks God to 'Enrich the time to come with smooth-faced peace' (Richard III, 5.6.36), Elizabethan spectators recognize their own enjoyment of 30 years of peace under Tudor rule. The last words of Shakespeare's history plays also fulfil a pragmatic function for the theatre company by acting as flashbacks and trailers to encourage audiences to return for the next episode. The Epilogue to Henry IV Part II announces that 'our humble author will continue the story' (25). The marketing function of last words in history plays is more targeted than the general promises of better performances in the comedies. Gray points out that trailers 'tell us what to expect, direct our excitement and / or apprehension' and offer clear points of identification (Gray, 2010: 49), something that is important in plays with very extensive dramatis personae like the history plays. Shakespeare's use of such advertisements is especially pronounced in the Henry VI plays, where Henry VI Part 1 was written after Parts II and III. At the end of the action-packed plot of Henry VI Part I, which features an English victory over the French and the death of a national military hero (Talbot), a change of direction is marked in the final scene where peace is made. Lord Suffolk, who has fallen in love with Margaret of Anjou and wooed her as a bride for King Henry VI, ends the play by directing spectators forward to Part II. The last words are both retrospective (in italics) and prospective (in bold):

Thus Suffolk hath prevailed and thus he goes As did the youthful Paris once to Greece With hope to find the like event in love But prosper better than the Trojan did. Margaret shall now be queen, and rule the King, But I will rule both her, the King, and realm. 
Having summarised his own victory and, by implication, that of the English army over the French in the words 'hath prevailed', Suffolk moves to a future marker to raise expectations about the next episode in the Henry VI series, exciting curiosity about what will happen. Gray warns that 'a trailer for an action film that concentrates too heavily on its romantic elements will read as a romance' (2010: 51). To attract the audience of the action-thriller that was Part I to return to theatre for Part II, Suffolk shifts from his own romantic epic as Paris wooing Helen (a rewriting of the ancient Troy story), to confide his strategic plan to usurp the King's power. This woos fans of the heroic action plot with the promise of a different kind of action: Machiavellian politics intertwined with adulterous romance.

In order to construct theatre-going (like cinema-going) as a repetitive event, the last words of history plays connect the historical world they dramatize and that of Elizabethan spectators. At the end of Henry VI Part II, Warwick the kingmaker intones that York's success 'Shall be eternized in all age to come,' invoking the weight of history, but then sends historical characters and Elizabethan spectators back to the same space with a reminder to return to the theatre: 'Sound drums and trumpets and to London all, / And more such days as these to us befall' (5.5.36-8). The long Epilogue to Henry IV Part II contains another marketing dimension: the spoiler. It points out that the author will 'continue the story with Sir John in it and make you merry with fair Catherine of France; where, for anything I know, Falstaff will die of a sweat' (Epilogue 25-7). Speakers addressing spectators outside the fiction on behalf of the author and company are generally held to be trustworthy (as noted above, this Epilogue calls his addressees 'my creditors' or believers, line 12), so this news would seem to discourage fans of the immensely popular Falstaff from returning to the theatre. Nevertheless, spoilers can, as their fans attest, 'reverse commonsense logic' and increase the pleasure of the text by allowing fans to 'take control of their emotional responses and pleasures of anticipation' (Gray, 2010: 153); and by 'creating as many questions as they answer' (Gray, 2010: 152). Fans of Falstaff are enticed to know how and where - and perhaps whether - he dies of a sweat (and are probably surprised to find that he never appears in Henry $V$ at all, never mind in France). It is significant that the Epilogue to Henry $V$, the last play in Shakespeare's great history cycle, uses no future marking verbs. It can only look back to a future that has already been written and performed in the Henry VI plays 'which oft our stage hath shown' (Epilogue 13). Although the Epilogue is a sonnet, it is also a farewell: 'our bending author' (Epilogue 2) has outgrown his love of English history. 


\subsection{Dispersion}

The right hand column of Table 1 shows that the frequency of words in Epilogues cannot always be taken as a feature of the genre. The dispersion of occurrences sometimes exposes the dense use of a word in one speech rather than as a characteristic of Epilogues as a whole. For example, 'good', the highest-ranked content word in Table 1, is a case in point (ranked 30 in Last Words; 18 in Epilogues in comparison to 44 in Rest of Play). 'Good' would be an appropriate adjective to appear in a final speech recommending a play for applause.

However, the dispersion figure for 'good' if we consider only content words is the highest in the Table (meaning the narrowest dispersion of the word) at 1.643 , because 10 of the occurrences are in the Epilogue to As You Like It. ${ }^{13}$

Another high figure very narrow dispersion is for 'my' at 1.513, where 13 of the 19 cases are in Henry IV Part II (with 2 in AYLI and 4 in Tempest). CQP web, which allows one to search frequencies in different genres, shows that the history plays have a higher density of use of this word than the comedies or tragedies (see below)

\section{Figure 2. Distribution of ' $m y$ ' across Comedies (C), Histories (H) and Tragedies (T)} from CQPweb Enhanced Shakespearean Corpus: First Folio Plus showing numbers of hits (first line of figures) category size (second row of figures) and frequency per million words (bottom row of figures)

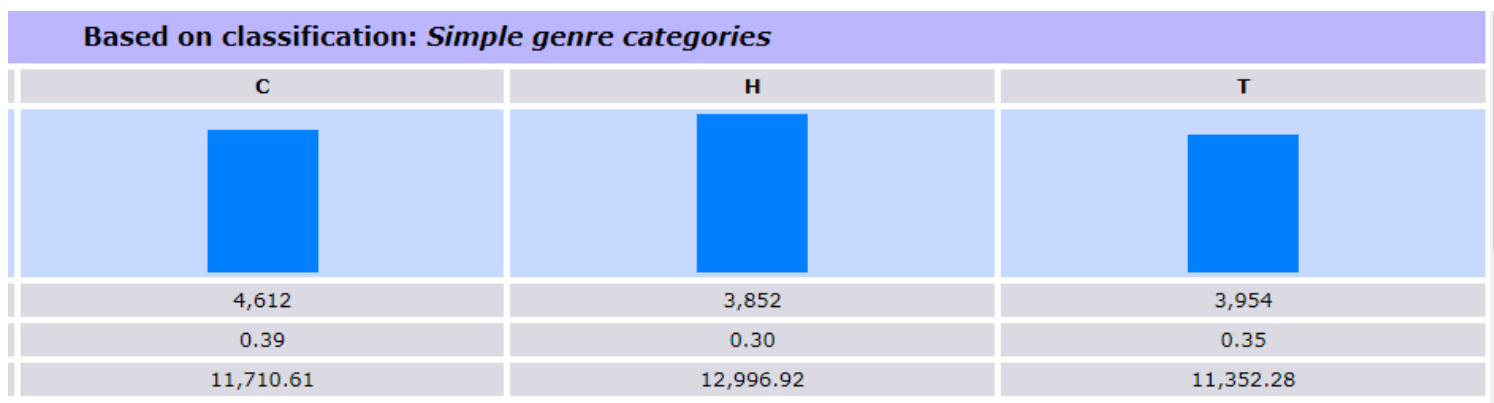

However, the high occurrence in the epilogue for Henry IV Part II is explained as a stylistic feature of that particular speaker. This suggests that Shakespeare's epilogues may be more usefully analysed as individual pieces crafted specifically for their occasions of performance. Stern (2009) has reasonably argued that epilogues and prologues 'cannot be used to make statements about the underlying nature of the text they adjoin' because they have a different occasional heritage from the play, and may not even be written by the author of the play (Stern 2009: 118). However, a corpus analysis of As You Like It, reveals a strong connection between the words of the epilogue and wider discursive features of the text as the following brief case study will show. 


\subsection{As You Like It: Epilogue and Text}

The boy actor who has played Rosalind (who has been cross-dressed as Ganymede) steps forward at the end of As You Like It to offer a female-voiced epilogue in contrast to Orlando's opening of the play:

It is not the fashion to see the Lady the Epilogue: but it is no more unhandsome than to see the Lord the Prologue. If it be true that good wine needs no bush, it is true that a good play needs no Epilogue. Yet to good wine they do use good bushes: and good plays prove the better by the help of good Epilogues. What a case am I in then, that am neither a good Epilogue, nor can not insinuate with you in the behalf of a good play? I am not furnished like a Beggar, therefore to beg will not become me. My way is to conjure you, and I 'll begin with the women. I charge you (O women) for the love you bear to men, to like as much of this play, as please you. And I charge you $(\mathrm{O}$ men) for the love you bear to women (as I perceive by your simpering, none of you hates them) that between you, and the women, the play may please. If I were a woman, I would kiss as many of you as had beards that pleased me, complexions that liked me, and breaths that I defied not. And I am sure, as many as have good beards, or good faces, or sweet breaths, will for my kind offer, when I make curtsy, bid me farewell.

(As You Like It, Epilogue)

The epilogue's repeated use of 'good' to describe wine, bushes, plays, epilogues, beards and faces reminds spectators of what has been a rigorous interrogation of the word 'good' and the values it connotes in the dialogue of the preceding play. Examples are marked in bold below. Statistically, As You Like It, uses 'good' more frequently (4.430 per million words) than all but two other Shakespeare plays (2HIV 4.722 per million words and $M W W 4,998$ per million words). 
Figure 3. Distribution of 'good' in those plays with the highest density of uses
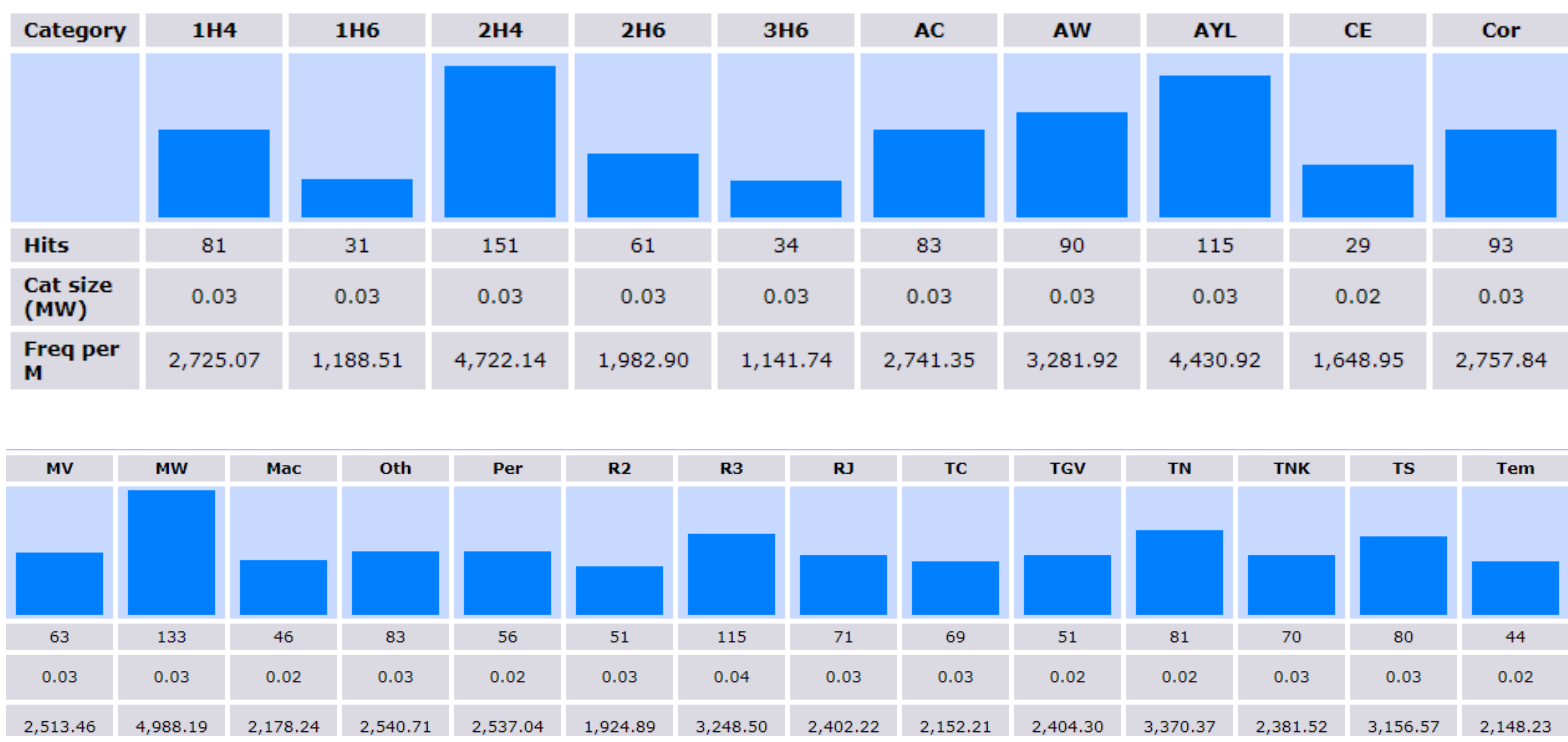

In As You Like It 'good' is used politely as a greeting in sincere (Rosalind: 'good even to you friend' 2.4.168) and insincere ways. Jacques and Orlando who dislike each other's philosophy, part with mock respect or affection, saying 'Adieu, good Signior Love' and 'Farewell, good Monsieur Melancholy' (3.2.386-7). Good as a marker of moral virtue is queried in the play in the contrast of Rosalind's deferential address to the usurping Duke Frederick as 'good my Liege' and those to the genuinely good Duke Senior 'Good my lord' (5.7). The play's highest valuation of moral goodness goes to the relatively humble servant Old Adam, the 'good old man' who gives his life savings to his master Orlando and follows him into the forest: 'how well in thee appears / The constant service of the antique world / When service sweat for duty not for meed!' (2.4.57)

The play's dialogue also interrogates the meaning of 'good' as fitting or appropriate. When Le Beau proposes that the ladies have lost 'much good sport' in the brutal wrestling match (1.2.94), Touchstone responds 'this is the first time that ever I heard breaking of ribs was sport for ladies' (1.2.128-9). Touchstone and Corin's witty debate on what are 'good' manners in the country and the court (3.2.39-47) likewise questions the relative appropriateness and value of courtly behaviour. Corin's 'philosophy' of the 'good' but simple life of the shepherd (3.23-30 and 71-5) is shared by Duke Senior who finds 'Sermons in stones and good in everything' (2.1.17) in the forest even though he has been usurped at court and driven into exile. His gentleness in welcoming Orlando and Adam recalls the principle of hospitality of 'good men's feasts' as a mark or moral goodness and civilized behaviour. Rosalind's romantic teasing of Orlando ('Are you not good? ... Can one desire too 
much of a good thing?' 4.1) contrasts with the meanness of Touchstone's evaluation of William in financial terms: 'So-so is good, very good, very excellent good. And yet it is not, it is but so-so.' (5.1.26-7). As Touchstone rightly points out, 'we that have good wits have much to answer for' (5.1.11). The play's witty but tenacious investigation of what it means to be good is echoed in the Epilogue.

The small grammatical word 'if', which begins Rosalind's reasoning about good wine, bushes, plays and Epilogues, and then her sentence about her own identity ('If I were a woman....') is a reminder of the play's rhetorical style, its emphasis on provisionality and dissolution of rigid boundaries and binaries. As You Like It makes the most frequent use of the word in the whole canon (138 occurrences in the play; relative frequency of 5,317 per million words), followed by Much Ado (4.920 per million words) and Merchant of Venice $(4,787)$ and Measure for Measure (4,245) (see below).

Figure 4. Distribution of 'if' in Enhanced Shakespearean Corpus: First Folio Plus with highest relative frequency in As You Like It, followed by Much Ado and Merchant of Venice
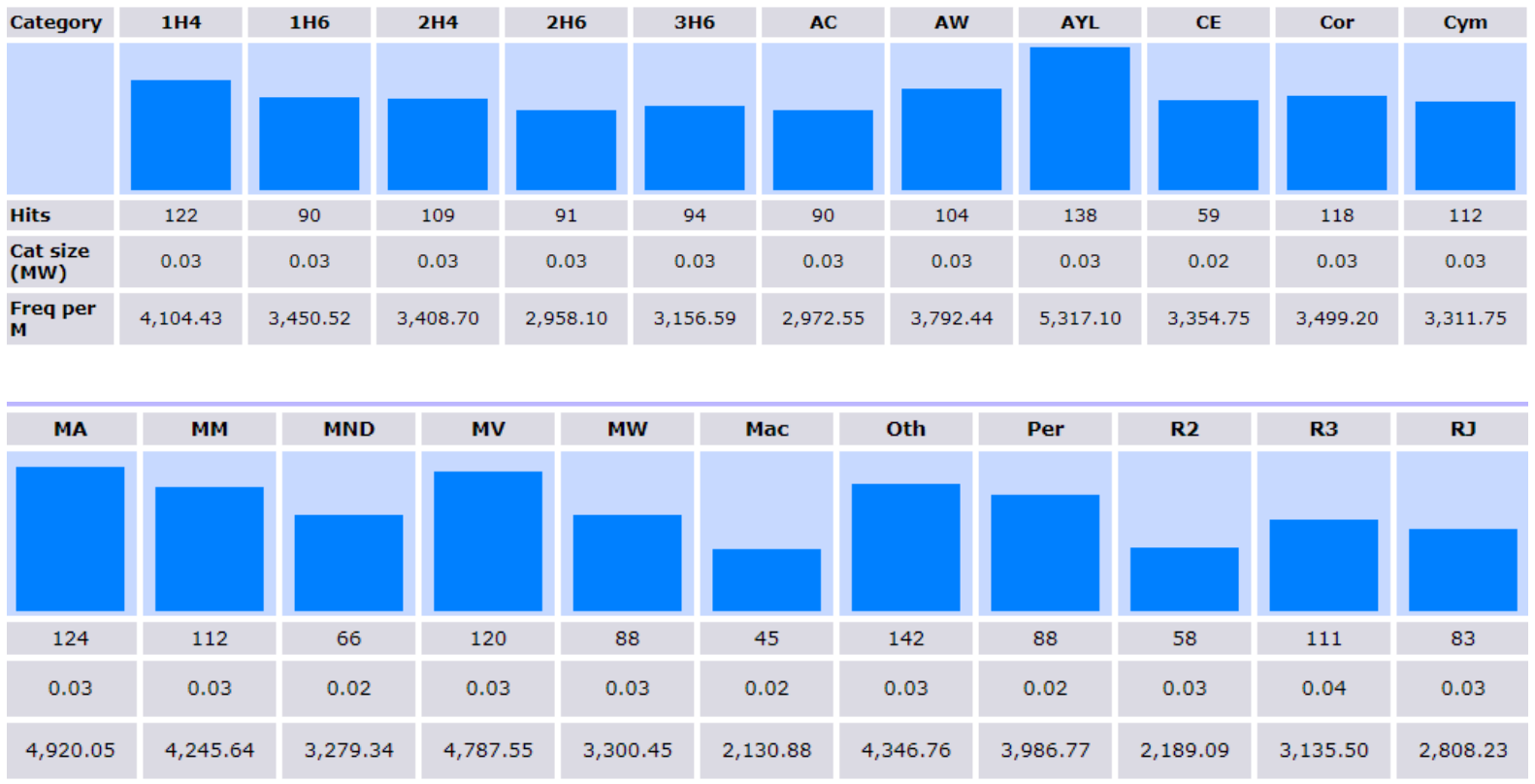

'If' is the key turning point in Touchstone's set piece on the degrees of the lie, from which he concludes that there is "Your "if" is the only peacemaker, much virtue in "if"' (5.4.98101). Rosalind exploits the 'if' of make believe by pretending to be the 'youth' Ganymede who then pretends to be Rosalind. Like Touchstone, she discovers there is 'much virtue in "if"" to resolve the romantic entanglements in the final scenes. 'If' occurs 15 times in 5.2, 
culminating with a series of promises by Rosalind / Ganymede to Phoebe 'I will marry you if ever I marry woman'; Orlando 'I will satisfy you, if ever I satisfied man' and Silvius 'I will content you, if what pleases you contents you and you shall be married tomorrow' (5.2.105112). When Rosalind appears as herself in 5.4. she fulfils her promises, telling the Duke, Orlando and Phoebe: 'I'll have no father if you be not he. I'll have no husband if you be not he. Nor never wed woman if you be not she' (5.4.120-22). The play's problematization of gender and sexual orientation, showing that they too are performative rather than fixed, depends on the contingency of 'if' which the final section of the Epilogue reiterates, beginning with the words 'If I were a woman.' As Belsey (1985) famously observed, the Epilogue compounds the uncertainty of who is speaking (inside or outside the fiction) by confusing the gender roles, not just in terms of the performer but the gender of the protagonist (1985: 181). This uncertainty runs throughout the play's romantic encounters, unsettling the straightforward heterosexual romance by opening up multiple possibilities for the expression of trans-sex identification and same-sex desire. It presents a continuum of shifting desire and gender identification; a queering of the text reflected in its title. The Epilogue undoes the heteronormative ordering celebrated in the weddings blessed by Hymen. Its command to 'women, to like as much of this play as please you' and to men that 'between you, and the women' the play may please, opens up a third space 'between' and reminds spectators of the multiple directions open to them, that have been demonstrated in the play.

Since Rosalind is the longest female role in Shakespeare, it is no surprise that the play's concerns with gender are evidenced in the prominence of the word 'women' which appears 3 times in the Epilogue and 11 times in the whole play. These are only small numbers but they are statistically significant in terms of frequency (423.83 per million words) in comparison to the other plays. The only other play which has a higher frequency of 'women' is Antony and Cleopatra (759.65), because Charmian and Iras are referred to as Cleopatra's 'women' in 10 of the 23 occurrences.

Figure 5. Distribution of 'women' in Enhanced Shakespearean Corpus: First Folio Plus with highest relative frequency in Antony and Cleopatra followed by As You Like It 


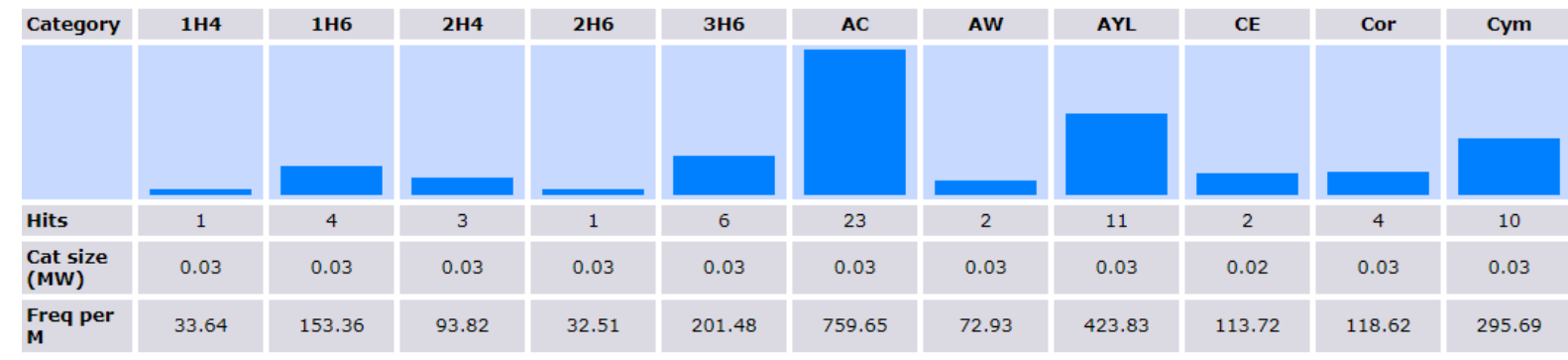

The Epilogue of As You Like It reminds readers and spectators that the boy actor playing Rosalind playing Ganymede explores the idea of what it means to be a woman, and Celia objects 'you have simply misused our sex in your love prate' (4.1.191), offering an important corrective against generalizations and caricatures. It is surely resonant that Jacques' famous speech is gender balanced: 'All the world's a stage / And all the men and women merely players' (2.7.139-40).

\section{Conclusion}

Sir Stanley Wells noted that 'it is a measure equally of Shakespeare's professionalism and of his artistic integrity that each play has its own voice' (Wells, 2020). The case study of As You Like It shows that corpus analysis helps us to identify that voice and, moreover, the Epilogue's important function in offering spectators a distillation of it. The Epilogue's few distinctive lines capture the essence of the play in an echoic souvenir that audiences can take away from the playhouse. Corpus analysis of the language of the last words of Shakespeare's plays also reveals aspects of their shared function as paratexts: to represent the community of the theatre company and to create a sense of community with playgoers, via inclusive forms of address. The power of terminal paratexts to shape spectators' and readers' impressions of what they have seen is realised through inclusive words like 'all' and 'Amen.' In a series of plays, such as Shakespeare's English histories, terminal paratexts work prospectively as well as retrospectively as a marketing tool for the theatre company, using techniques like trailers and even spoilers that we are familiar with nowadays from television and film. Gower's Epilogue to Pericles, 'New joy wait on you. Here our play has ending', encapsulates the fragile liminal moment where characters, actors and audience are united by their experience of the performance and the imminent dispersal of everyone along new paths. The epilogue is a farewell; its appeal for applause for what has been is there in the words 'our play has ending' but it is accompanied by good wishes for the future: 'New joy wait on you'. The new joys may be in the world beyond the playhouse doors, but they may also be the result of 
discoveries made by experiencing the play. What the company can promise is that 'new joy' awaits them if they return to the theatre.

\section{Funding}

The research presented in this article was supported by the UK's Arts and Humanities Research Council (AHRC), grant reference AH/N002415/1.

\section{Acknowledgments}

I thank Isolde Van Dorst and Jonathan Culpeper for their help with acquiring the data for Table 1 and Andrew Hardie for his continuing work to maintain and develop CQPweb.

\section{References}

Barasch FK (1995) 'He's for a Iigge or a tale of Baudry': Sixteenth-Century Images of the Stage-Jig. Shakespeare Bulletin, 13(1) (1995): 24-8.

Baskervill CR (1929) The Elizabethan Jig and Related Song Drama. Chicago: University of Chicago Press.

Bray T, Paoli, J, Sperberg-McQueen, CM, Maler, E and Yergeau, F (2008) (eds) Extensible Markup Language (XML) 1.0. Fifth edition. W3C Recommendation 26 November 2008. https://www.w3.org/XML/ (accessed 01.06.2019).

Belsey C (1985) Disrupting sexual difference: meaning and gender in the comedies. In Drakakis J (ed) Alternative Shakespeares. London and New York: Routledge, pp.166-90. Baskervill CR (1929) The Elizabethan Jig. Chicago: University of Chicago Press.

Clegg R and Skeaping L (2014) Singing Simpkin and other Bawdy Jigs: Musical Comedy on the Shakespearean Stage, Scripts, Music and Context. Exeter: University of Exeter Press.

Clegg R and Thomson P (2009) 'He's for a jig or a tale of bawdry-':notes on the English dramatic jig, Studies in Theatre and Performance, 29:1, 67-83. 
Coleridge ST (2014) Biographia Literaria or biographical sketches of my literary life and opinions [1817]. Ed. Roberts A. Edinburgh: Edinburgh University Press.

Findlay A (2019) Experiencing Time in Shakespeare's Theatre. Shakespeare.15(3): 223-32.

Foucault M (1977) What is an Author? trans. D Bouchard and S Simon. In Bouchard (ed) Language, Counter-Memory, Practice. Oxford: Basil Blackwell, pp.113-38.

Genette G (1997) Paratexts, trans. JE Lewin. Cambridge: Cambridge University Press.

Goffman E (1979) Footing. Semiotica 25 (1-2): 1-29.

Goffman E (1986) Frame Analysis: An Essay on the Organization of Experience. Boston, MA: Northeastern University Press. First published Cambridge, MA: Harvard University Press [1974].

Gray J (2010) Show Sold Separately: Promos, Spoilers and Other Media Paratexts. New York and London: New York University Press.

Hardie A (2012) CQPweb - combining power, flexibility and usability in a corpus analysis tool. International Journal of Corpus Linguistics 17 (3): 380-409.

Hardie, A (2014) Modest XML for corpora: not a standard, but a suggestion. ICAME Journal 38: 73-103.

Messerli TC (2017) Participation structure in fictional discourse: authors, scriptwriters, audiences and characters. In Locher MA and Jucker AH (eds) Pragmatics of Fiction, Berlin and Boston: DeGruyter, pp.25-54.

Peacham H (1612) Minerva Britanna or a garden of heroical devises furnished, and adorned with emblems and impresa's of sundry natures. London: Wa. Dight.

Taylor G, Jowett J, Borus T and Egan G (2016) The New Oxford Shakespeare: The Complete Works, Modern Critical Edition. Oxford: Oxford University Press. 
Schneider BW (2013) The Framing Text in Early Modern English Drama: 'Whining'

Prologues and 'Armed' Epilogues. Farnham: Ashgate.

Shakespeare W (1988) The Complete Works. (Eds) Wells S and Taylor G. Oxford: Clarendon Press.

Sherman WH (2011) Terminal paratexts and the birth of print culture. In Smith H and Wilson L (eds) Renaissance Paratexts. Cambridge: Cambridge University Press, pp. 65-87.

Solomon D (2013) Prologues and Epilogues of Restoration Theater: Gender and Comedy, Performance and Print. Lanham: University of Delaware Press.

Stern T (2009) Documents of Performance in Early Modern England. Cambridge: Cambridge University Press, 2009).

Stern T (2010) Epilogues, prayers after plays and Shakespeare's Henry IV. Theatre Notebook 64(3) 122-9.

Wells S (2020) How did Shakespeare write a play? In Lecture Series: 'What Was Shakespeare Really Like?', Shakespeare Birthplace Trust, Stratford-on-Avon https://www.shakespeare.org.uk/explore-shakespeare/podcasts/what-was-shakespearereally/how-did-shakespeare-write-a-play/\# [Accessed 28 June 2020]

\section{Notes}

${ }^{1}$ For easy location, all quotations from Shakespeare are referenced by the Act, Scene and line numbers from the Oxford Shakespeare (1988) which is based on the First Folio (1623), the text used for the corpus analysis.

2 There are additional uses of finis to mark the end of the first act in Two Gentlemen of Verona, Love's Labour's Lost, and Twelfth Night (which also has finis at the end of Acts 2 and 4). This appears sometimes before and sometimes after the stage direction Exeunt.

${ }^{3}$ On the Jig as a terminal paratext, see Baskervill (1929); Barasch (1995), who discusses the jig's connections with Italian commedia, and Clegg and Thomson (2009) and Clegg and Skeaping (2014) on the jig in performance. 
${ }^{4}$ For details of CQP web see

http://www.research.lancs.ac.uk/portal/en/upmprojects/cqpweb(855e22e7-97fb-4863-91019b245729ccbd).html.

${ }^{5}$ I am grateful to Isolde Van Dorst and Jonathan Culpeper for their help with acquiring the data for Table 1 and presenting it.

${ }^{6}$ This does not include Much Ado About Nothing which, as noted above, ends with a dance.

${ }^{7}$ The male suitors' masque of Muscovites in Love's Labour's Lost concludes with the

Rosaline's scornful 'Break off, break off' (5.2.262) and the pageant of the Nine worthies is interrupted by Marcade's entrance with news of the King of France's death and Berowne's abrupt 'Worthies away. The scene begins to cloud' (5.2.714). 'Pyramus and Thisbe ends with a bergomask (5.1.355), the fairy entertainment in Merry Wives ends with confusion as Alice Page and Slender elope and Falstaff is pinched (5.5.101SD).

${ }^{8}$ For details of \#LancsBox see: http://corpora.lancs.ac.uk/lancsbox/

9 The masculine pronoun is used because all actors in Shakespeare's company were men or boys who played female characters.

${ }^{10}$ This phrase is Samuel Taylor Coleridge's from his Biographia literaria (1817) and is more appropriate to the darkened auditoria of later theatre history than the open air or candlelit auditoria in which Shakespeare's plays were originally performed and where spectators were fully visible to each other. See Coleridge (2014), p. 208.

${ }^{11}$ For a fuller reading of the play's Tudor politics see Findlay (2019).

${ }^{12}$ Only one occurrence of 'will' in the Last Words is as a noun, Pandarus telling spectators 'my will shall here be made' (Troilus and Cressida, Epilogue 17). This instance is balanced by the omission of 'We'll' in the last words following the May-day Morris entertainment in Two Noble Kinsman (3.5.148).

13 'Goodnight' which occurs in Midsummer Night's Dream, Henry IV Part 2, and Two Noble Kinsmen is treated as one word by CQPweb and so is not included in the statistics. 